\title{
Convective suppression before and during the United States Northern Great Plains flash drought of 2017
}

\author{
Tobias Gerken ${ }^{1,2}$, Gabriel T. Bromley ${ }^{1}$, Benjamin L. Ruddell ${ }^{2}$, Skylar Williams ${ }^{1}$, and Paul C. Stoy ${ }^{1}$ \\ ${ }^{1}$ Montana State University, Department of Land Resources and Environmental Sciences, Bozeman, MT 59717, USA \\ ${ }^{2}$ Northern Arizona University, School of Informatics, Computing, and Cyber Systems, Flagstaff, AZ 86011, USA
}

Correspondence: Tobias Gerken (tobias.gerken@montana.edu)

Received: 17 April 2018 - Discussion started: 7 May 2018

Revised: 20 July 2018 - Accepted: 27 July 2018 - Published: 7 August 2018

\begin{abstract}
Flash droughts tend to be disproportionately destructive because they intensify rapidly and are difficult to prepare for. We demonstrate that the 2017 US Northern Great Plains (NGP) flash drought was preceded by a breakdown of land-atmosphere coupling. Severe drought conditions in the NGP were first identified by drought monitors in late May 2017 and rapidly progressed to exceptional drought in July. The likelihood of convective precipitation in May 2017 in northeastern Montana, however, resembled that of a typical August when rain is unlikely. Based on the lower tropospheric humidity index $\left(\mathrm{HI}_{\mathrm{low}}\right)$, convective rain was suppressed by the atmosphere on nearly $50 \%$ of days during March in NE Montana and central North Dakota, compared to $30 \%$ during a normal year. Micrometeorological variables, including potential evapotranspiration $\left(\mathrm{ET}_{\mathrm{p}}\right)$, were neither anomalously high nor low before the onset of drought. Incorporating convective likelihood to drought forecasts would have noted that convective precipitation in the NGP was anomalously unlikely during the early growing season of 2017. It may therefore be useful to do so in regions that rely on convective precipitation.
\end{abstract}

\section{Introduction}

Rapid onset "flash" droughts (Otkin et al., 2017) due to extreme heat or precipitation deficit (Mo and Lettenmaier, 2016) are difficult to predict and prepare for and thus tend to be disproportionally destructive (Ford and Labosier, 2017). An unprecedented flash drought took place across parts of the US Northern Great Plains (NGP) and Canadian Prairie
Provinces during the 2017 vegetative growing season (Fig. 1) that in some areas was the worst in recorded history.

Even though abnormally dry conditions were reported by agricultural producers in northeastern Montana as early as late April (Montana DNRC, 2017), the 2017 NGP flash drought was not foreseen in the seasonal forecast. The US National Weather Service Climate Prediction Center's (CPC) 3-month (JJA) seasonal forecast issued on 18 May 2017 reported above-average precipitation probabilities across the NGP. Severe drought conditions (D2 as classified by the US Drought Monitor, USDM, Svoboda et al., 2002) began in late May to early June 2017 in the central Dakotas and then extended westward toward Montana (Fig. 1; Table 1). At the peak of the drought in early September, nearly three-fourths of Montana was under extreme (D3) or exceptional (D4) drought. Nearly two-thirds of North Dakota was under severe to exceptional drought in mid-August, and more than half of South Dakota was under severe to exceptional drought in mid-July, causing acute and ongoing economic and ecological impacts across the region.

The USDM is a diagnostic product that combines the Palmer Drought Severity Index (PDSI, Palmer, 1965; Alley, 1984) with US Geological Survey stream flow, soil moisture observations (Fan and van den Dool, 2004), the Standardized Precipitation Index (Guttman, 1998, 1999), and expert knowledge. As such and as intended, it provides a useful tool for tracking and displaying drought across the US (Svoboda et al., 2002), but does not provide information about the meteorological conditions causing the drought. Here, we demonstrate that an established approach for diagnosing the likelihood of convective precipitation (Findell and Eltahir, 2003a, b) as applied to the NGP (Gerken et al., 2018) in- 
(a)

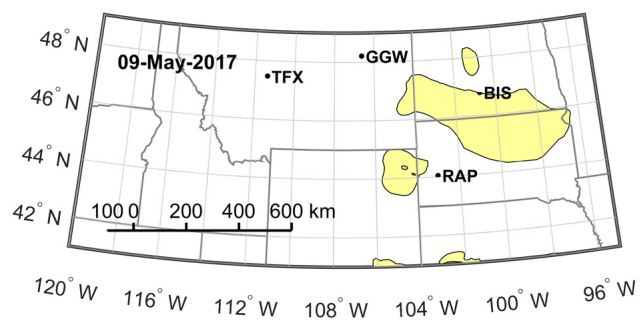

(c)

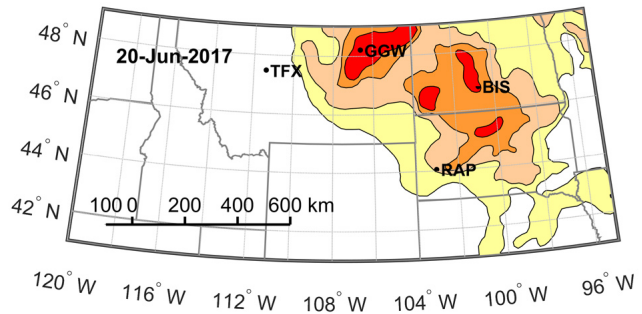

(e)

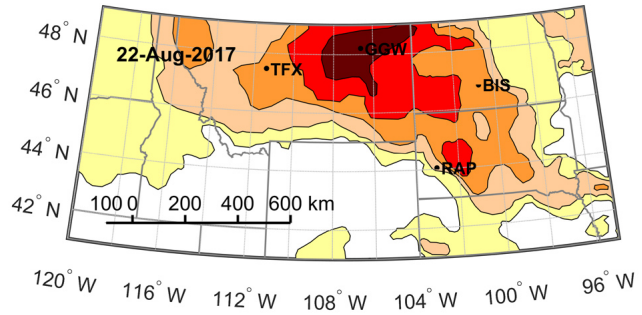

(b)

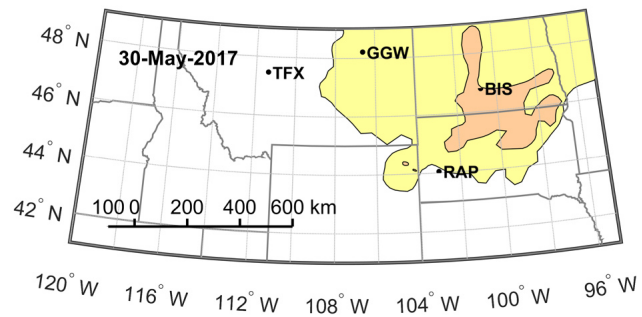

(d)

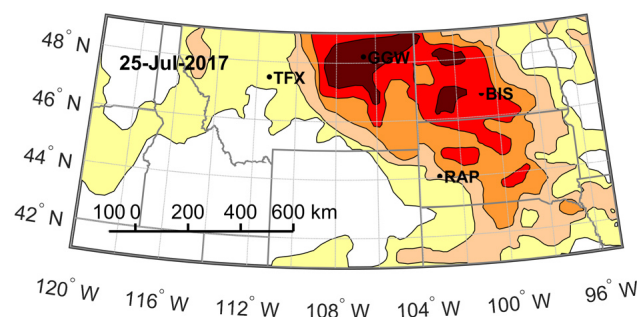

(f)

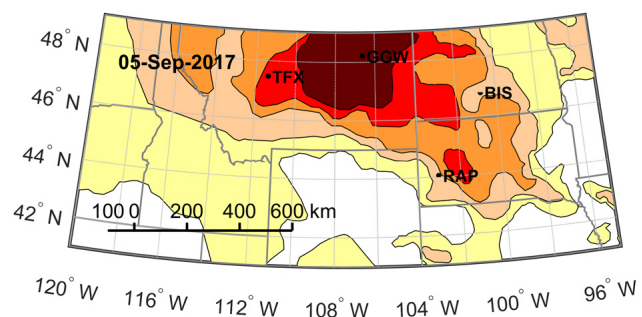

Figure 1. The US Drought Monitor classification of the 2017 Northern Great Plains flash drought during the weeks of (a) 9 May 2017, (b) 30 May 2017, (c) 20 June 2017, (d) 25 July 2017, (e) 22 August 2017, and (f) 5 September 2017. The locations of atmospheric sounding stations at Bismarck, Rapid City, Glasgow, and Great Falls are indicated. The dates were chosen according to drought development stages at the sites. D0 (abnormally dry) - yellow; D1 (moderate drought) - tan; D2 (severe drought) - orange; D3 (extreme drought) - red; D4 (exceptional drought) - dark red.

dicated that convective precipitation was unlikely to occur in the regions impacted by drought as early as March 2017 due to an anomalously dry lower atmosphere. Locally triggered convective events are not the volumetrically dominant water source for precipitation - weather systems contribute approximately $60 \%$ of total warm season precipitation in the US Great Plains (Carbone and Tuttle, 2008) - but provide a critical moisture source during the vegetative growing season. We argue that it may therefore be useful to include convective likelihood to drought monitors and forecasts in regions where convective precipitation is an important moisture source.

\section{Data and methods}

Convective precipitation in the NGP is part of a transitional regime characterized by both wet and dry landatmosphere coupling (Findell and Eltahir, 2003b). Conditions alternate between atmospheric control of convective precipitation during the late growing season and periods dur- ing which changes in surface energy balance partitioning can lead to crossings between mixed-layer height and the lifted condensation level during the early vegetative growing season (Gerken et al., 2018). Such crossings are considered a necessary but not sufficient condition for the development of convective precipitation (Juang et al., 2007a, b).

To diagnose convective likelihood, we use atmospheric profiles of air temperature $(T)$ and humidity $(q)$ following Findell and Eltahir (2003a, b) to calculate the convective triggering potential (CTP) and the lower tropospheric humidity index $\left(\mathrm{HI}_{\text {low }}\right)$, a measure of atmospheric dryness:

$$
\mathrm{HI}_{\text {low }}=\left(T_{50}-T_{\mathrm{d}, 50}\right)+\left(T_{150}-T_{\mathrm{d}, 150}\right) .
$$

$\mathrm{HI}_{\text {low }}$ is based on Lytinska et al. (1976) and calculated from the sum of dew point depressions (the difference between $T$ and dew point temperature $T_{\mathrm{d}}$ ) at 50 and $150 \mathrm{hPa}$ above the ground level. CTP is the energy released by a hypothetical saturated air parcel that ascends from 100 to $300 \mathrm{hPa}$ above the ground level and is thus a measure of atmospheric instability (Findell and Eltahir, 2003a, b) and closely related 
Table 1. Climate stations from Global Historical Climatology Network (GHCN) and onset of drought stages (D0-D4, according to the US Drought Monitor, USDM) for the 2017 drought.

\begin{tabular}{lllllllll}
\hline Location & Code $^{\mathrm{a}}$ & GHCN ID & Coordinates & Onset D0 & Onset D1 & Onset D2 & Onset D3 & Onset D4 \\
\hline Bismarck, ND & BIS & USW00024011 & $46.783^{\circ} \mathrm{N} ; 100.757^{\circ} \mathrm{W}$ & 9 May & 30 May & 6 Jun & 20 Jun & - \\
Rapid City, SD & RAP & USW00024090 & $44.043^{\circ} \mathrm{N} ; 103.054^{\circ} \mathrm{W}$ & 6 Jun & 13 Jun & - & - & - \\
Great Falls, MT & TFX & USW00024143 & $47.793^{\circ} \mathrm{N} ; 111.382^{\circ} \mathrm{W}$ & 25 Jul & 8 Aug & 22 Aug & 5 Sep & - \\
Glasgow, MT & GGW & USW00094008 & $48.241^{\circ} \mathrm{N} ; 106.621^{\circ} \mathrm{W}$ & 30 May & 6 Jun & 13 Jun & 20 Jun & 25 Jul \\
\hline
\end{tabular}

a National Weather Service station code.

$\mathrm{b}$ The USDM reported moderate drought conditions (D1) for Rapid City during winter 2016-2017. On 2 May 2017 abnormally dry conditions (D0) no longer persisted at Rapid City.

to convective available potential energy (CAPE):

$$
\mathrm{CTP}=\int_{100 \mathrm{hPa}}^{300 \mathrm{hPa}} R_{\mathrm{d}}\left(T_{\mathrm{v}, \mathrm{sp}}-T_{\mathrm{v}, \mathrm{e}}\right) \mathrm{d} \ln p,
$$

with $T_{\mathrm{v}, \mathrm{sp}}$ and $T_{\mathrm{v}, \mathrm{e}}$ as virtual temperatures of a saturated air parcel and the environment, the specific gas constant for dry air $\left(R_{\mathrm{d}}\right)$, and pressure $(p)$.

Based on early morning sounding data in Illinois, USA, it was originally proposed that convection did not develop for CTP $<0 \mathrm{~J} \mathrm{~kg}^{-1}$ due to lack of available energy, whereas the lower atmosphere was too dry to develop boundary-layer clouds and associated precipitation if $\mathrm{HI}_{\text {low }}>15^{\circ} \mathrm{C}$ (Findell and Eltahir, 2003a, b). Later research established different thresholds for convective likelihood across different regions (Ferguson and Wood, 2011; Roundy et al., 2012), and we have established that convective development is unlikely for $\mathrm{HI}_{\text {low }}$ greater than approximately $20^{\circ} \mathrm{C}$ at Glasgow, Montana (GGW), near the centroid of the 2017 drought (Fig. 1) (Gerken et al., 2018). We use this value as indicative of the threshold beyond which convective precipitation is unlikely to develop for the study region.

We calculated CTP and $\mathrm{HI}_{\text {low }}$ for 12:00 UTC (corresponding to 05:00 MST) using daily vertical radiosonde profiles of $T$ and $q$ for the period 1987 to 2017 from the University of Wyoming Upper Air Sounding Archive (http:// weather.uwyo.edu/upperair/sounding.html, last access: August 2018). Four stations located in the NGP were selected: Bismarck, ND (code: BIS, GHCN ID: 72764); Rapid City, SD (RAP, 72662); Great Falls, MT (TFX, 72776); and Glasgow, MT (GGW, 72768) (Table 1). Sounding operations at TFX commenced in September 1994 and data are not available beforehand.

Daily precipitation $(P)$ and daily average $T$ data for the four locations (Table 1) were obtained from the Global Historical Climatology Network (GHCN) daily product described in Menne et al. (2012a, b). $T$ and $P$ data from Great Falls International Airport were chosen instead of the adjacent Great Falls Weather Forecast Office (TFX, the sounding location) due to its longer data record that spans the analysis period. Daily data for the 30-year period from 1987 to 2016 were averaged to estimate the $T$ and $P$ climatology at the four study sites. $P$ occurring on 29 February was attributed to 28 February to compute the $P$ climatology.

Drought maps of the NGP and surrounding regions were created using geographic shapefiles downloaded from the US Drought Monitor (Svoboda et al., 2002). The drought monitor uses a blend of data sources to classify drought status between abnormally dry (D0), moderate (D1), severe (D2), extreme (D3), and exceptional drought (D4).

We also analyze potential evapotranspiration $\left(\mathrm{ET}_{\mathrm{p}}\right)$ given recent findings that previous flash droughts were preceded by anomalously high evaporative stress (Otkin et al., 2016; Ford and Labosier, 2017). In the absence of direct measurements, daily $\mathrm{ET}_{\mathrm{p}}$ was estimated from standard weather data, obtained from the Integrated Surface Dataset (global hourly), following the protocol established by the Food and Agriculture Organization (FAO) and outlined in Allen et al. (1998). The FAO Penman-Monteith equation for a reference crop is

$\mathrm{ET}_{\mathrm{p}}=\frac{0.408 \Delta\left(R_{\mathrm{n}}-G\right)+\gamma \frac{900}{T_{2}+273} u_{2} \mathrm{VPD}}{\Delta+\gamma\left(1+0.34 u_{2}\right)}$,

where $R_{\mathrm{n}}$ is net radiation at the land surface; $G$ is soil heat flux and assumed to be zero at the daily timescale; $T_{2}$ and $u_{2}$ are the mean daily air temperature and wind speed at $2 \mathrm{~m}$ height, respectively; VPD is the vapor pressure deficit; $\Delta$ is the slope of saturation vapor pressure curve; and $\gamma$ is the psychrometric constant. Missing climatic data were treated according to the protocol outlined in Allen et al. (1998), such that for example $R_{\mathrm{n}}$ was derived using daily temperature range $\left(T_{\max }-T_{\min }\right)$, estimated extraterrestrial radiation $R_{a}$, and an estimate for net longwave radiation based on the Stefan-Boltzmann law; see Eqs. (20)-(26) and Eqs. (35)(40) in the FAO document (Allen et al., 1998) for details.

\section{Results}

A comparison between 30-year average $P$ totals and cumulative $P$ during 2017 reiterates that 2017 was much drier than average at all four sounding locations in the NGP (Fig. 2). In a typical year, more than $50 \%$ of the annual $P$ in the NGP occurs from April to June during the main vegetative growing season, but there is considerable interannual vari- 


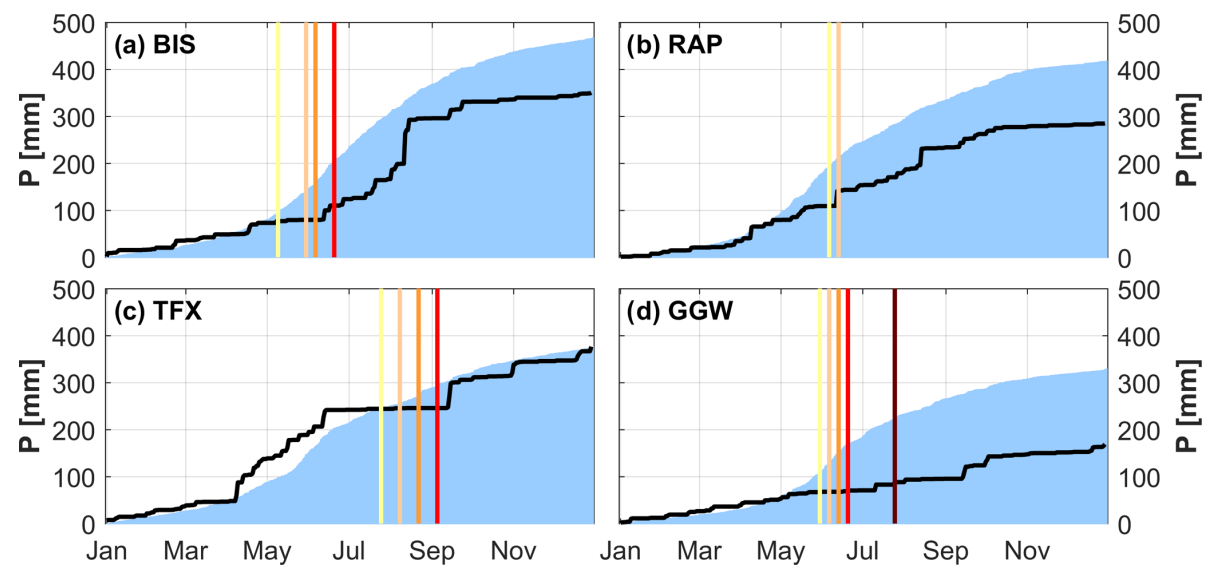

Figure 2. Cumulative annual precipitation for 2017 (black line) compared to 30-year average precipitation (1987-2016, shaded area) for (a) Bismarck, ND; (b) Rapid City, SD; (c) Great Falls, MT; and (d) Glasgow, MT. Vertical lines indicate onset of drought (D0 - yellow to D4 - dark red).

ability (Fig. S1 in the Supplement). During the first 100 days of 2017, precipitation totals were close to the climatological mean at all four stations. After that, BIS, RAP, and GGW reported below-average precipitation between April and August. At GGW, there was almost no reported precipitation during spring and summer 2017. TFX, which initially reported above-average precipitation in April and May, experienced a 3-month period from late June to September (ca. DOY 175-250) with virtually no precipitation (Fig. 2).

In addition to $P, T$ (Fig. S2), and the USDM (Fig. 1), drought development in the NGP can also be investigated from the atmospheric (e.g., boundary-layer) perspective. Applying the CTP-HI $\mathrm{H}_{\text {ow }}$ framework (Findell and Eltahir, 2003a, b) reveals strong atmospheric control on precipitation in May at BIS and GGW (Fig. 3) preceding the USDM onset of severe drought (D2) conditions in the NGP. At GGW, near the centroid of the region that experienced exceptional drought (Fig. 1), average $\mathrm{HI}_{\text {low }}$ for May 2017 was nearly $25^{\circ} \mathrm{C}$. This far exceeded the value of $20^{\circ} \mathrm{C}$ beyond which convective precipitation is unlikely. May 2017 conditions were more like a typical August, when rainfall is less likely (Fig. 2).

Across the four study sites, monthly mean CTP increased from less than $0 \mathrm{~J} \mathrm{~kg}^{-1}$ in April 2017 to the $150-250 \mathrm{~J} \mathrm{~kg}^{-1}$ range in September, indicating conditions during which convective development is not limited by atmospheric stability. At the same time, average monthly $\mathrm{HI}_{\text {low }}$ values increased, indicating increasing atmospheric dryness, which can limit convective precipitation (Findell and Eltahir, 2003a, b). Atmospheric profiles during July and August in the NGP are very dry on average and little convective precipitation is expected during an average year (Fig. 3), especially for TFX and GGW.

The dryness of atmospheric profiles (via $\mathrm{HI}_{\text {low }}$ ) during 2017 preceded surface drought conditions in the NGP (Table 1, Figs. 1 and 3). At BIS, D0 conditions started on 9 May, whereas the percentage of days characterized by convective

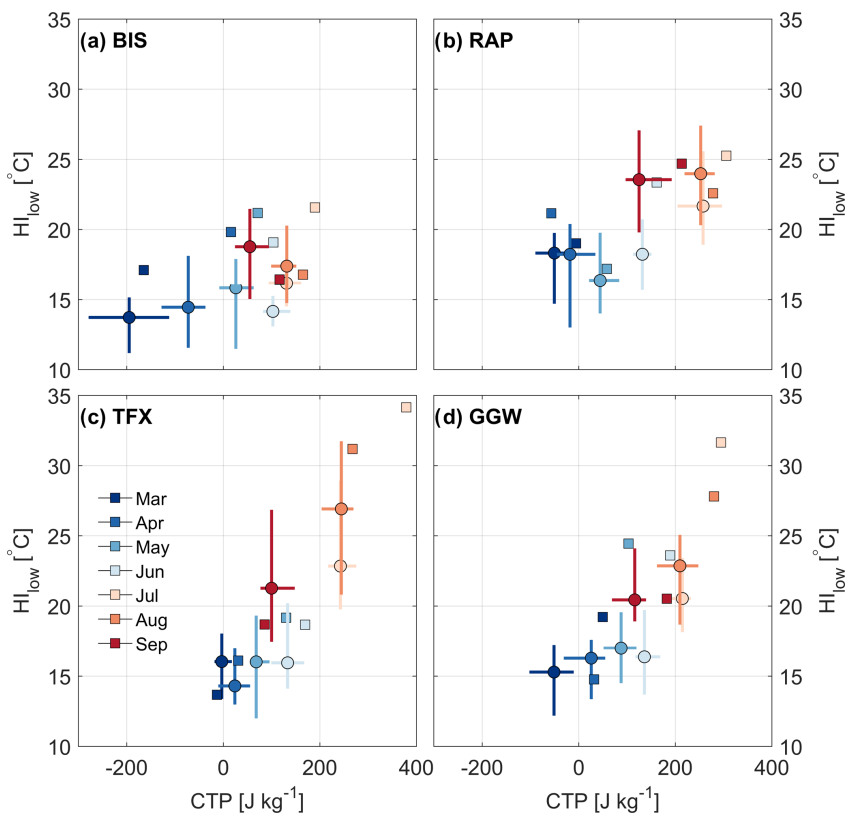

Figure 3. Seasonal development of mean monthly convective triggering potential (CTP) and lower tropospheric humidity index $\left(\mathrm{HI}_{\text {low }}\right)$ for 2017 (squares) compared to 30-year (1987-2016) median (circles) and interquartile range (lines) of CTP and $\mathrm{HI}_{\text {low }}$ for (a) Bismarck, ND (BIS); (b) Rapid City, SD (RAP); (c) Great Falls, MT (TFX); and (d) Glasgow, MT (GGW).

suppression, indicated by $\mathrm{HI}_{\text {low }}>20^{\circ} \mathrm{C}$, exceeded the climatological 75th percentile already in late March (Fig. 4). A similar situation arose for GGW, which was most affected by the drought: the probability of convective precipitation was anomalously low before and during May 2017 (Figs. 3 and 4d), yet the USDM showed 30 May and 6 June for D0 and D1 conditions, respectively. RAP, on the other hand, shows the smallest lead in $\mathrm{HI}_{\text {low }}$ compared to the other sites. May 
conditions were close the climatological mean, which was followed by rapid atmospheric drying during June and corresponded to the onset of D0 conditions on 6 June. RAP did not experience D2 or greater conditions during 2017.

\section{Discussion}

Our findings suggest that a careful study of convective likelihood may provide further information for regional drought forecasts. Convective precipitation was far less likely than usual at BIS and GGW before the flash drought in 2017 as revealed by the monthly and daily CTP-HI low analyses (Figs. 3 and 4). The running mean of days in which convective precipitation was unlikely (Fig. 4) suggests that GGW and BIS experienced anomalously dry conditions in mid-late March ("anomalous" is defined here as the fraction of days during which the likelihood of convective precipitation exceeded the climatological interquartile range). In other words, there were atmospheric clues that conditions were drier than normal before the flash drought across part of the domain that experienced drought conditions (Fig. 1). Notably, this period of low convective likelihood coincided with the period of the vegetative growing season which is the climatologically wettest (Fig. 2). At the other stations, in contrast, such conditions either occur much later (TFX) or are less severe (RAP), thus limiting rapid drought intensification and severity. This differing behavior further highlights the likely importance of convectively unfavorable conditions and atmospheric control for drought.

Observations that convective precipitation was anomalously low well before drought onset (Fig. 4) are consistent with the notion that flash droughts are preceded by a breakdown in surface-atmosphere feedbacks, as has been found in other studies of different drought events. For example, Myoung and Nielsen-Gammon (2010a, b) demonstrated the instrumental role of low soil moisture and associated convective inhibition on drought in Texas, and Juang et al. (2007a) noted a threshold in soil moisture and RH below which convective precipitation did not form in the Piedmont region of North Carolina. In the NGP, convective precipitation rarely occurs at near-surface relative humidities below ca. 50-60\% (Gerken et al., 2018), which may provide an approximate rule of thumb for convective precipitation likelihood in areas like the NGP where sounding stations are separated by hundreds of kilometers (Fig. 1). The present study likewise shows that there might be clues in the coupled surfaceatmosphere system that indicate when a flash drought may emerge. However, our findings are derived from a single flash drought event. To generalize our findings and to potentially establish effective metrics to estimate flash drought onset, the historic record of flash droughts should be investigated to detect similar clues.
It remains to be seen if the CTP-HI $\mathrm{H}_{\text {low }}$ analysis explored here is a robust method for forecasting flash droughts in other regions and for other drought events, and a critical course of future research is to do so in the context of other approaches for studying drought onset. For example, the evaporative stress index was anomalously high before the 2012 drought in the central Great Plains (Otkin et al., 2016) and VPD and $\mathrm{ET}_{\mathrm{p}}$ were anomalously high before flash droughts in the eastern US (Ford and Labosier, 2017). Successive desiccation of soils, leading to deep, warm, and dry atmospheric convective boundary layers was found to be an important contributor to heat waves (Miralles et al., 2014).

A similar connection between evaporative demand and drought is also found in during spring and summer in the NGP (Fig. 5, see Fig. S4 for total annual $\mathrm{ET}_{\mathrm{p}}$ ). All four sites transitioned to D0 conditions during periods for which $\mathrm{ET}_{\mathrm{p}}$ exceeded the climatological median by at least one quartile. Drought intensification at BIS, RAP, and GGW occurred during an extended period of high evaporative demand, which could not be met by the typically dry soils. $\mathrm{ET}_{\mathrm{p}}$ was not anomalously high for extended periods before the onset of drought at BIS and RAP, but was greater than average for 25 days before the onset of D0 drought at GGW, and for an even longer period before D0 drought at TFX, which was declared after D4 exceptional drought conditions emerged at GGW (Table 1) and drought mitigation was underway in the State of Montana.

The unusually high $2017 \mathrm{ET}_{\mathrm{p}}$ could be primarily attributed to its sensitivity to VPD (Fig. 6). At the same time, wind speeds at GGW and BIS also play a role in elevated $\mathrm{ET}_{\mathrm{p}}$ values, whereas near-surface $T$ was found to be less important. Since no direct observations of historic $R_{\mathrm{n}}$ were available at the stations, such that $R_{\mathrm{n}}$ for $\mathrm{ET}_{\mathrm{p}}$ calculation was estimated primarily from solar position and temperature as suggested by FAO, it is not feasible to assess the role of abnormal energy input on $\mathrm{ET}_{\mathrm{p}}$. However, due to high VPDs and the development of general drought conditions, it can be presumed that cloud cover was low, thus leading to largerthan-normal solar irradiance. This, likely, further increased $\mathrm{ET}_{\mathrm{p}}$, highlighting the importance of land-atmosphere feedbacks in drought development. The interpretation of $\mathrm{ET}_{\mathrm{p}}$ effects and sensitivity to drought development should be made cognizant of the fact that $R_{\mathrm{n}}$ was estimated and thus subject to associated uncertainties. At the same time, recent work (Milly and Dunne, 2016, 2017) found Penman-Monteithbased $\mathrm{ET}_{\mathrm{p}}$ estimates to be overly sensitive in response to climate change. Based on the reported low cloud cover during the drought, it is likely that the impact of energy supply is underrepresented in the current work.

The interaction between drying soils, boundary-layer processes, evaporative demand, and convection for drought is also in agreement with findings that the timing of convection initiation in the Canadian Prairie Provinces is influenced by soil moisture (Hanesiak et al., 2004). Also, CPC soil moistures (Fan and van den Dool, 2004) became anomalously low 


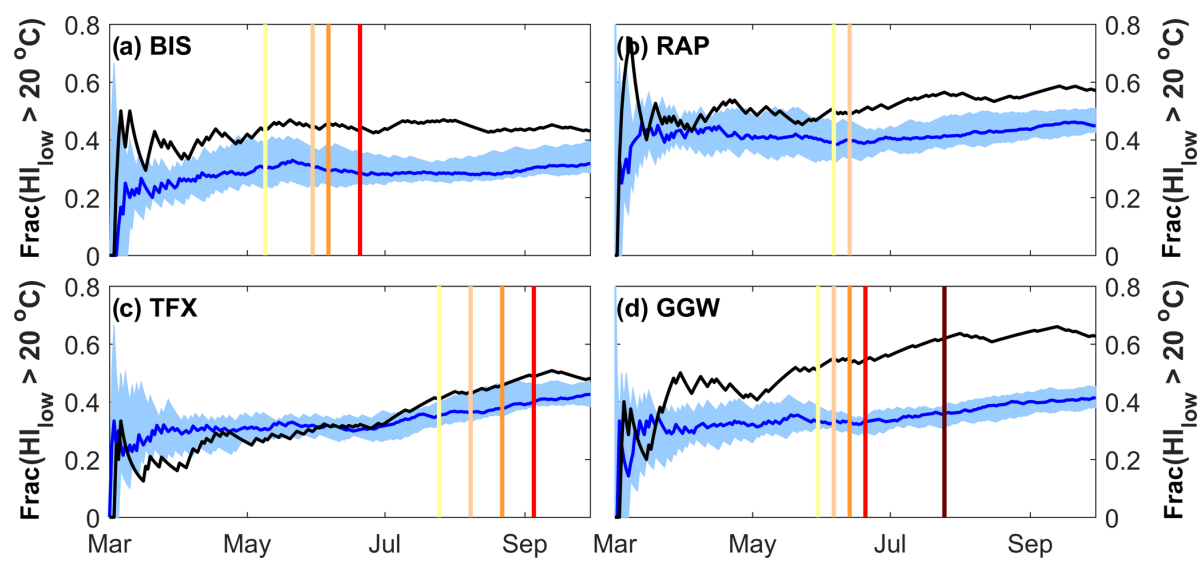

Figure 4. Cumulative fraction of days from March $1(\mathrm{DOY}=60)$ to 30 September with the lower troposphere humidity index $\mathrm{HI}_{\mathrm{low}}$ exceeding $20^{\circ} \mathrm{C}$ - taken to be the value above which convective precipitation is unlikely - for 2017 (black line) compared to the 30-year median (blue line) and interquartile range (shaded area) for (a) Bismarck, ND; (b) Rapid City, SD; (c) Great Falls, MT; and (d) Glasgow, MT. Vertical lines indicate onset of drought (D0 - yellow to D4 - dark red).
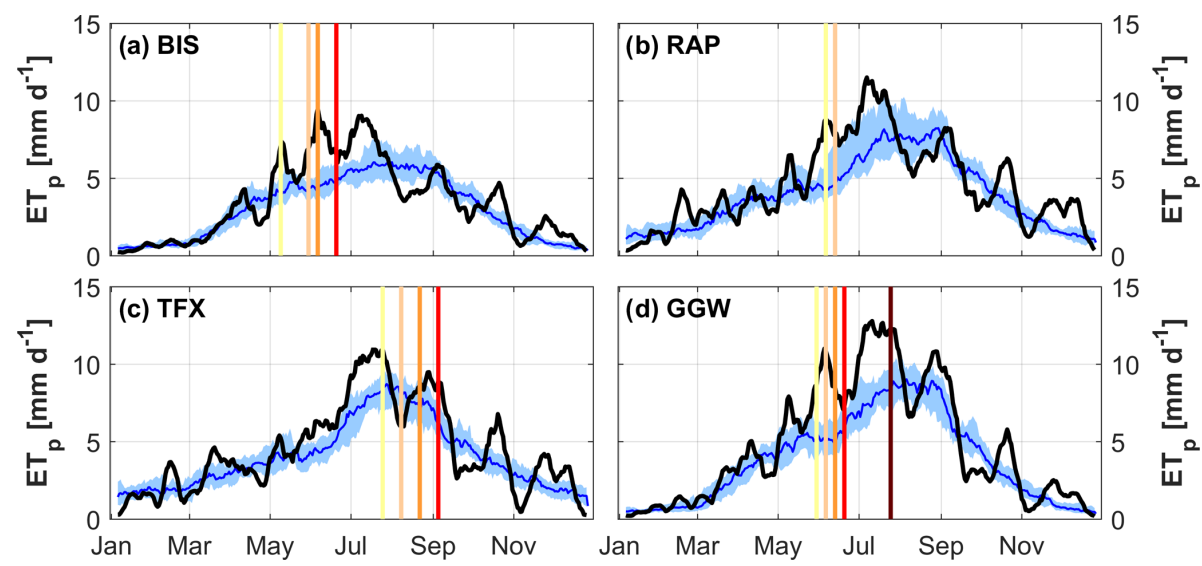

Figure 5. Estimated $\mathrm{ET}_{\mathrm{p}}$ for 2017 (black line), compared to 30-year median (blue line) and interquartile range (shaded area) for (a) Bismarck, ND; (b) Rapid City, SD; (c) Great Falls, MT; and (d) Glasgow, MT. Vertical lines indicate onset of drought (D0 - yellow to D4 - dark red). $\mathrm{ET}_{\mathrm{p}}$ values were smoothed by applying a 10-day running mean.

(rank below 30th percentile) in the Dakotas and northeastern Montana from June 2017 onwards. Given the difficulties of providing accurate root zone soil moistures, despite recent advances in observations and modeling, the CTP-HI low framework might provide an additional early warning signal for drought forecasting.

There are a number of additional factors at play that should be studied in concert with the likelihood of convective precipitation for a comprehensive understanding of the hydroclimatic conditions that precede flash drought in the NGP and elsewhere. Mesoscale convective systems provide a large fraction of total summertime precipitation in the Great Plains (Carbone and Tuttle, 2008; Tuttle and Davis, 2006), and the conditions that favor or suppress them provide an important control over drought development. Flash drought forecasting should also be cognizant of shifting land surface conditions that may have important consequences for the coupled soil- vegetation-atmosphere system (Otkin et al., 2016). Recent shifts in climate and precipitation in the NGP for example are consistent with shifts in agricultural management that impact soil moisture and boundary-layer dynamics (Gameda et al., 2007; Betts et al., 2013, 2014; Mahmood et al., 2014; Vick et al., 2016), such that the 30-year mean climatological conditions studied here are part of an ongoing trend in landatmosphere coupling. Recent studies also suggest that the arid-humid divide across the North American Great Plains - often approximated as the 100th meridian in the US - may be shifting eastward in response to global climatic changes (Seager et al., 2018). Regardless, atmospheric conditions favoring convective suppression preceded the 2017 NGP flash drought and may have provided robust inference into its prediction. 

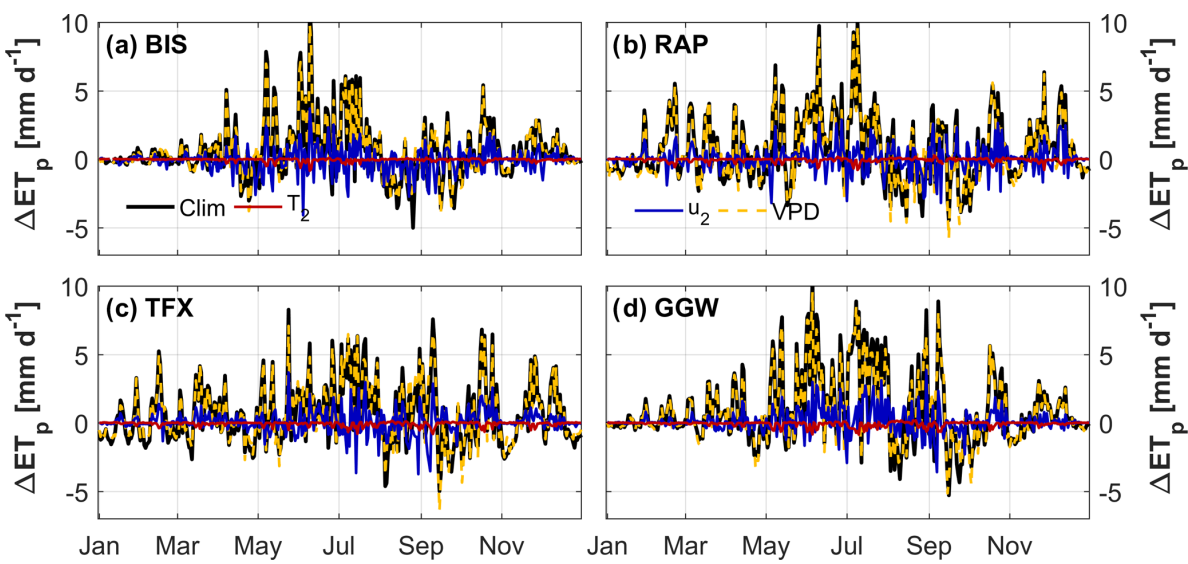

Figure 6. Change of $\mathrm{ET}_{\mathrm{p}}$ compared to estimated $\mathrm{ET}_{\mathrm{p}}$ of 2017 ( $\Delta \mathrm{ET}_{\mathrm{p}}$ ) for (a) Bismarck, ND; (b) Rapid City, SD; (c) Great Falls, MT; and (d) Glasgow, MT. $\triangle E_{\mathrm{p}}$ is calculated by using the climatological averages of $T_{2}, u_{2}$, and VPD, respectively, instead of 2017 values, while "Clim" corresponds to ET $\mathrm{p}$ calculated from the climatology. $\Delta \mathrm{ET}_{\mathrm{p}}$ values were smoothed by applying a 10-day running mean.

\section{Conclusions}

Our findings show that the NGP flash drought was exacerbated by a breakdown of land-atmosphere interactions and predominance of atmospheric control on convective initiation during the early growing season that countered the decadal trend of moistening in the NGP and increased landatmosphere coupling (Gerken et al., 2018). Ruddell and Kumar (2009) similarly found drought to be associated with a breakdown of the self-organizing moisture feedback process between surface and atmosphere. In the light of recent changes in land management for the NGP away from summer fallow and investment towards more water-demanding crops (Miller et al., 2002; Long et al., 2014), reliable drought early warning systems become increasingly important. Integrating information about convective inhibition into drought monitoring and drought early warning systems might be advisable based on this study, especially in regions characterized by high or variable degrees of land-atmosphere coupling where land surface and atmospheric observations provide information about precipitation likelihood. A critical course of future research and to generalize our findings beyond a single case is to compare the conditions that precede flash droughts using multiple metrics in order to provide the best possible inference for drought forecasts in the US and across the globe.

Data availability. Data to reproduce figures are available to the public from the National Oceanic and Atmospheric Administration's (NOAA) Global History Climatology Network (GHCN, https://doi.org/10.7289/V5D21VHZ, Menne et al., 2012), NOAA's Integrated Surface Dataset (ISD, https://doi.org/10.1175/2011BAMS3015.1, Smith et al., 2011), and the University of Wyoming (http://weather.uwyo.edu/upperair/, last access: August 2018).
USDM data in the form of shapefiles were obtained from http://droughtmonitor.unl.edu (National Drought Mitigation Center, 2017).

Supplement. The supplement related to this article is available online at: https://doi.org/10.5194/hess-22-4155-2018-supplement.

Competing interests. The authors declare that they have no conflict of interest.

Acknowledgements. We acknowledge support from the National Science Foundation (NSF) Office of Integrated Activities (OIA) 1632810, the NSF Division of Environmental Biology (DEB) 1552976, the US Department of Agriculture National Institute of Food and Agriculture (USDA-NIFA) Hatch project 228396, the Montana Wheat and Barley Committee, and The Graduate School at Montana State University. BLR acknowledges support from NSF Emerging Frontiers (EF) 1241960. We thank Larry Oolman for maintaining the Upper Air Sounding Archive at the University of Wyoming. The US Drought Monitor (USDM) is jointly produced by the National Drought Mitigation Center at the University of Nebraska-Lincoln (NDMC-UNL), the United States Department of Agriculture, and the National Oceanic and Atmospheric Administration. Map information courtesy of NDMC-UNL. We thank Tanja Fransen (National Weather Service Forecast Office Glasgow, MT) as well as Buddhi Achhami, Adam Cook, Hannah Goemann, Audrey Harvey, and Jim Junker (Montana State University) for helpful comments on a draft version of this manuscript. We thank two anonymous reviewers for their thoughtful comments.

Edited by: Bob Su

Reviewed by: two anonymous referees 


\section{References}

Allen, R. G., Pereira, L. S., Raes, D., and Smith, M.: Crop Evapotranspiration - Guidelines for computing crop water requirements, Tech. Rep. 56, Food and Agricultural Organization, Rome, available at: http://www.fao.org/docrep/X0490E/ x0490e00.htm (last access: August 2018), 1998.

Alley, W. M.: The Palmer Drought Severity Index: Limitations and assumptions, J. Climate Appl. Meteor., 23, 1100-1109, https://doi.org/10.1175/15200450(1984)023<1100:TPDSIL>2.0.CO;2, 1984.

Betts, A. K., Desjardins, R., Worth, D., and Cerkowniak, D.: Impact of land use change on the diurnal cycle climate of the Canadian Prairies, J. Geophys. Res.-Atmos., 118, 11996-12011, https://doi.org/10.1002/2013JD020717, 2013.

Betts, A. K., Desjardins, R., Worth, D., and Beckage, B.: Climate coupling between temperature, humidity, precipitation, and cloud cover over the Canadian Prairies, J. Geophys. Res.-Atmos., 119, 2014JD022511, https://doi.org/10.1002/2014JD022511, 2014

Carbone, R. E. and Tuttle, J. D.: Rainfall occurrence in the U.S. warm season: The diurnal cycle, J. Climate, 21, 4132-4146, https://doi.org/10.1175/2008JCLI2275.1, 2008.

Fan, Y. and van den Dool, H.: Climate Prediction Center global monthly soil moisture data set at $0.5^{\circ}$ resolution for 1948 to present, J. Geophys. Res., 109, D10102, https://doi.org/10.1029/2003JD004345, 2004.

Ferguson, C. R. and Wood, E. F.: Observed land-atmosphere coupling from satellite remote sensing and reanalysis, J. Hydrometeor., 12, 1221-1254, https://doi.org/10.1175/2011JHM1380.1, 2011.

Findell, K. L. and Eltahir, E. A. B.: Atmospheric controls on soil moisture-boundary layer interactions. Part I: Framework development, J. Hydrometeor., $4, \quad 552-569, \quad \mathrm{https} / / /$ doi.org/10.1175/15257541(2003)004<0552:ACOSML>2.0.CO;2, 2003a.

Findell, K. L. and Eltahir, E. A. B.: Atmospheric controls on soil moisture-boundary layer interactions. Part II: Feedbacks within the continental United States, J. Hydrometeor., 4, 570-583, https://doi.org/10.1175/15257541(2003)004<0570:ACOSML>2.0.CO;2, 2003 b.

Ford, T. W. and Labosier, C. F.: Meteorological conditions associated with the onset of flash drought in the Eastern United States, Agr. Forest Meteorol., 247, 414-423, https://doi.org/10.1016/j.agrformet.2017.08.031, 2017.

Gameda, S., Qian, B., Campbell, C., and Desjardins, R.: Climatic trends associated with summer fallow in the Canadian Prairies, Agr. Forest Meteorol., 142, 170-185, https://doi.org/10.1016/j.agrformet.2006.03.026, 2007.

Gerken, T., Bromley, G. T., and Stoy, P. C.: Surface moistening trends in the northern North American Great Plains increase the likelihood of convective initiation, J. Hydrometeor., 19, 227-244, https://doi.org/10.1175/JHM-D-17-0117.1, 2018.

Guttman, N. B.: Comparing the Palmer Drought Index and the Standardized Precipitation Index, J. Am. Water Resour. Assoc., 34, 113-121, https://doi.org/10.1111/j.1752-1688.1998.tb05964.x, 1998.

Guttman, N. B.: Accepting the Standardized Precipitation Index: A calculation algorithm, J. Am. Water Resour. Assoc., 35, 311322, https://doi.org/10.1111/j.1752-1688.1999.tb03592.x, 1999.
Hanesiak, J. M., Raddatz, R. L., and Lobban, S.: Local Initiation of deep convection on the Canadian Prairie Provinces, Bound.-Lay. Meteorol., 110, 455-470, https://doi.org/10.1023/B:BOUN.0000007242.89023.e5, 2004.

Juang, J.-Y., Katul, G. G., Porporato, A., Stoy, P. C., Siqueira, M. S., Detto, M., Kim, H.-S., and Oren, R.: Eco-hydrological controls on summertime convective rainfall triggers, Glob. Change Biol., 13, 1-10, https://doi.org/10.1111/j.1365-2486.2006.01315.x, $2007 a$.

Juang, J.-Y., Porporato, A., Stoy, P. C., Siqueira, M. S., Oishi, A. C., Detto, M., Kim, H.-S., and Katul, G. G.: Hydrologic and atmospheric controls on initiation of convective precipitation events, Water Resour. Res., 43, W03421, https://doi.org/10.1029/2006WR004954, 2007b.

Long, J. A., Lawrence, R. L., Miller, P. R., Marshall, L. A., and Greenwood, M. C.: Adoption of cropping sequences in northeast Montana: A spatio-temporal analysis, Agriculture, Ecosystems \& Environment, 197, 77-87, https://doi.org/10.1016/j.agee.2014.07.022, 2014.

Lytinska, Z., Parfiniewicz, J., and Piwkowski, H.: The prediction of air mass thunderstorms and hails, in: Proc. WMO Symp. on the Interpretation of Broad-Scale NWP Products for Local Forecasting Purposes, vol. 450, 128-130, WMO, Warsaw, 1976.

Mahmood, R., Pielke, R. A., Hubbard, K. G., Niyogi, D., Dirmeyer, P. A., McAlpine, C., Carleton, A. M., Hale, R., Gameda, S., Beltrán-Przekurat, A., Baker, B., McNider, R., Legates, D. R., Shepherd, M., Du, J., Blanken, P. D., Frauenfeld, O. W., Nair, U., and Fall, S.: Land cover changes and their biogeophysical effects on climate, Int. J. Climatol., 34, 929-953, https://doi.org/10.1002/joc.3736, 2014.

Menne, M. J., Durre, I., Korzeniewski, B., McNeill, S., Thomas, K., Yin, X., Anthony, S., Ray, R., Vose, R. S., Gleason, B. E., and Houston, T. G.: Global Historical Climatology Network - Daily (GHCN-Daily), Version 3, https://doi.org/10.7289/V5D21VHZ, 2012a.

Menne, M. J., Durre, I., Vose, R. S., Gleason, B. E., and Houston, T. G.: An Overview of the Global Historical Climatology Network-Daily Database, J. Atmos. Oceanic Technol., 29, 897910, https://doi.org/10.1175/JTECH-D-11-00103.1, 2012b.

Menne, M. J., Durre, I., Korzeniewski, B., McNeal, S., Thomas, K., Yin, X., Anthony, S., Ray, R., Vose, R. S., Gleason, B. E., and Houston, T. G.: Global Historical Climatology Network - Daily (GHCN-Daily), Version 3.22 NOAA National Climatic Data Center, https://doi.org/10.7289/V5D21 VHZ (last assess: January 2018), 2012.

Miller, P. R., McConkey, B. G., Clayton, G. W., Brandt, S. A., Staricka, J. A., Johnston, A. M., Lafond, G. P., Schatz, B. G., Baltensperger, D. D., and Neill, K. E.: Pulse crop adaptation in the Northern Great Plains, Agron. J., 94, 261-272, 2002.

Milly, P. C. D. and Dunne, K. A.: Potential evapotranspiration and continental drying, Nature Clim. Change, 6, 946-949, https://doi.org/10.1038/nclimate3046, 2016.

Milly, P. C. D. and Dunne, K. A.: A hydrologic drying bias in water-resource impact analyses of anthropogenic climate change, J. Am. Water Resour. Assoc., 53, 822-838, https://doi.org/10.1111/1752-1688.12538, 2017.

Miralles, D. G., Teuling, A. J., van Heerwaarden, C. C., and VilàGuerau de Arellano, J.: Mega-heatwave temperatures due to combined soil desiccation and atmospheric heat accumulation, 
Nature Geosci., 7, 345-349, https://doi.org/10.1038/ngeo2141, 2014.

Mo, K. C. and Lettenmaier, D. P.: Precipitation deficit flash droughts over the United States, J. Hydrometeor., 17, 11691184, https://doi.org/10.1175/JHM-D-15-0158.1, 2016.

Montana DNRC: Montana Drougth Impacts and Outlook, Tech. Rep. May 2017, The Montana Department of Natural Resources \& Conservation, available at: http://dnrc.mt.gov/ divisions/water/drought-management/drought-documents/ drought-report-documents/MTDroughtReportMAY2017.pdf (last access: August 2018), 2017.

Myoung, B. and Nielsen-Gammon, J. W.: The convective instability pathway to warm season drought in Texas. Part I: The role of convective inhibition and its modulation by soil moisture, J. Climate, 23, 4461-4473, https://doi.org/10.1175/2010JCLI2946.1, 2010a.

Myoung, B. and Nielsen-Gammon, J. W.: The convective instability pathway to warm season drought in Texas. Part II: Freetropospheric modulation of convective inhibition, J. Climate, 23, 4474-4488, https://doi.org/10.1175/2010JCLI2947.1, $2010 \mathrm{~b}$.

National Drought Mitigation Center: USDM data, available at: http: //droughtmonitor.unl.edu (last access: October 2017), 2017.

Otkin, J. A., Anderson, M. C., Hain, C., Svoboda, M., Johnson, D., Mueller, R., Tadesse, T., Wardlow, B., and Brown, J.: Assessing the evolution of soil moisture and vegetation conditions during the 2012 United States flash drought, Agr. Forest Meteorol., 218219, 230-242, https://doi.org/10.1016/j.agrformet.2015.12.065, 2016.

Otkin, J. A., Svoboda, M., Hunt, E. D., Ford, T. W., Anderson, M. C., Hain, C., and Basara, J. B.: Flash droughts: a review and assessment of the challenges imposed by rapid onset droughts in the united states, B. Am. Meteor. Soc., 99, 911-919, https://doi.org/10.1175/BAMS-D-17-0149.1, 2017.
Palmer, W. C.: Meteorological Drought, Tech. Rep. 45, US Department of Commerce, Weather Bureau, Washington, D.C., 1965.

Roundy, J. K., Ferguson, C. R., and Wood, E. F.: Temporal variability of land-atmosphere coupling and its implications for drought over the Southeast United States, J. Hydrometeor, 14, 622-635, https://doi.org/10.1175/JHM-D-12-090.1, 2012.

Ruddell, B. L. and Kumar, P.: Ecohydrologic process networks: 1. Identification, Water Resour. Res., 45, W03419, https://doi.org/10.1029/2008WR007279, 2009.

Seager, R., Feldman, J., Lis, N., Ting, M., Williams, A. P., Nakamura, J., Liu, H., and Henderson, N.: Whither the 100th Meridian? The once and future physical and human geography of America's arid-humid divide. Part II: The meridian moves east, Earth Interact., 22, 1-24, https://doi.org/10.1175/EI-D-170012.1, 2018.

Smith, A., Lott, N., and Vose, R.: The Integrated Surface Database: Recent Developments and Partnerships, B. Am. Meteorol. Soc., 92, 704-708, https://doi.org/10.1175/2011BAMS3015.1, 2011.

Svoboda, M., LeComte, D., Hayes, M., Heim, R., Gleason, K., Angel, J., Rippey, B., Tinker, R., Palecki, M., Stooksbury, D., Miskus, D., and Stephens, S.: The Drought Monitor, B. Am. Meteor. Soc., 83, 1181-1190, https://doi.org/10.1175/1520-047783.8.1181, 2002.

Tuttle, J. D. and Davis, C. A.: Corridors of warm season precipitation in the central United States, Mon. Weather Rev., 134, 22972317, https://doi.org/10.1175/MWR3188.1, 2006.

Vick, E. S., Stoy, P. C., Tang, A. C., and Gerken, T.: The surface-atmosphere exchange of carbon dioxide, water, and sensible heat across a dryland wheat-fallow rotation, Agriculture, Ecosystems \& Environment, 232, 129-140, https://doi.org/10.1016/j.agee.2016.07.018, 2016. 